\title{
Budget in Nigerian Public Sector: Need for Balanced Scorecard Perspective
}

\author{
Abdullahi A Malgwi ${ }^{1}$, Angus O. Unegbu ${ }^{2, *}$ \\ ${ }^{1}$ Department of Accountancy, University of Maiduguri, Borno State Nigeria \\ ${ }^{2}$ School of Business \& Entrepreneurship, American University of Nigeria Yola, Adamawa State Nigeria
}

\begin{abstract}
The word budget has been traced to its origin. Budget performance in Borno, Bauchi, Yobe, Taraba and Adamawa, all in Nigeria has been investigated specifically on how budget performances differ from State to State. Four budget performance indices appraisals were used. ANOVA and Pair Wise Correlation statistical tools were employed in the analysis of data collected. The results showed that budget performance differs significantly with $\mathrm{p}=0.001$ from state to state with $\mathrm{F}>13.118$ tested at 5\% level of significance. This paper recommended the adoption of Balanced Scorecard Budget Perspectives and close monitoring of budget execution should be enshrined in the country's work ethics so as to strengthen other measures in mitigating public corruption in Nigeria.
\end{abstract}

Keywords Public Sector Budgets, Budget Performance, Budget Monitoring, Nigeria

\section{Introduction}

The word 'budget' originated from a French word bougette meaning little bag. In Britain, the word was used to describe the leather bag in which the chancellor of the exchanger used to carry to the parliament the statement of government needs and sources as described by[1]. After several thoughts of consensus, the budget became the document contained in the bags which represent plans of government expressed in money and submitted to legislatives for approval.

Government use budgets as a guiding tool for planning and control of its resources, be it financial or otherwise. The use of budget involves knowing how much money you earn and spend over a period, particularly one year. When a budget of an establishment, department or ministry is created, it means creating a plan for spending and saving money.

The process of preparing budget requires a call circular to the various departments, establishments, ministry or representatives who are expected to participate in the budget discussion as well as serve as budget committees. The person who heads the budget committee is known as the budget director. The budget director heads the budget committee and receives departmental or organizational submissions for onward transmission to the chairman for authentication and verification. On receipt of the budget submission, the chairman is expected to go through the documents, make any

\footnotetext{
* Corresponding author:

unegbu4@yahoo.com (Angus O. Unegbu)

Published online at http://journal.sapub.org/ijfa

Copyright (C) 2012 Scientific \& Academic Publishing. All Rights Reserved
}

necessary adjustment, corrections, modifications, additions based on the mission or corporate objectives, and then forward it to the legislative arm of the council as a bill document. The legislative council reads the budget document carefully, discuss every aspect of it, make any amendment if any and send it to the Executive for his consent and authentication. Once the executive sign the document, it becomes a legal document to use for spending and control of money at any tier of government. It should be noted that any department, establishment or ministry has a vote on which funds can be drawn, thus budget not only serves as an instrument of revenue/expenditure estimation but also as a catalyst for mitigating corruption in the use of public resources for the good of the state. Nigeria is now ranked as one of the most corrupt nations of the world and aspiring to be among the top 20th economies of the world by the year 2020 but she is yet to adopt Balanced Scorecard in her budgeting processes and implementations. A balanced scorecard budget perspective aligns budget strategy with objectives and incorporates performance measures at the time of setting out the budget. Key indicator of performance and growth is the embedment of budget discipline at all the tiers of government, thus money spent must be justified and satisfied by all the established budgetary and budget monitoring organs and this is the locus of Balanced Scorecard perceptive of Public Sector Budget.

The aim of this paper is to evaluate budget in the public sector from balanced scorecard perspectives. Towards this purpose, the specific objectives of the study are to investigate how budget performance differs from state to state in Nigeria and to carry out a correlation appraisal surveyed States and responses obtained on budget performances of the selected 
states in Nigeria from years 2000 to 2010.

\section{Theoretical Framework}

There exist several definitions of budgets from authoritative sources, but the common thread that cut across all the definitions is the plan of activities linked with financial resources. People (Organization) use time to communicate with each other but there are different languages of time just as there are different spoken languages, this is the view of[2]. Budget in that wise is a means of communicating to business stakeholders in monetary terms of what the Firm/Organizati on intends to spend and how much revenue they intend to generate from that expenditure for a given period. Concurring with time based definition of budget,[3] had it that budget is a detailed plan for acquiring and using financial and other resources over a specified time period. It represents a plan for the future expressed in formal quantitative terms. Government over the years has been preparing budgets for anticipated revenues and anticipated expenditures. Anticipated revenues of government includes recurrent revenues, consolidated revenues, grants, fines and licenses, incomes from rented government properties, federal allocations and a host of others, while anticipated expenditures includes recurrent expenditures, personnel costs, administration, maintenance cost and capital expenditures.

Budget had been defined by[4] as an accounting device used to plan and control resources of Operational Departments of Governments and Divisions. These definitions and explanations of budget are alike but this paper adopted the concept of budget defined by[1] as a financial and/or quantitative statement, prepared and approved prior to a defined period of time, of the policy to be pursued during that period for the purpose of attaining a given objective.

Budgeting mission is to touch the lives of people at the grassroots by incorporating what people need to better their lives. Education, health, power, roads, water and shelter are not exceptions. Budgeting involves understanding of how much money you earn and spend over a period of time. When you create a budget, you are creating a plan for spending and saving money through control. The budget is used as an instrument to tract the flow of resources. The control aspect of budget tries to monitor, ensure that every naira must be justified to fulfill the budget purpose. Other functions of budget as propounded by[5] include; regulate Corporate areas of expected revenues and actual expenditures, provides resources for execution of projects, acts as a means of checks and balances in financial administration, and gives rooms for proper auditing and accounting of Public revenue. According to[6] one of the fundamental uses of budget is the 'control' functions. To him, budget is a financial plan which is prepared based on the expectations of the future activities and is used to control those activities.

In Governmental circles, as opined by[7] budgets are used to assist management control and to provide the legal authority to levy taxes, collect revenue and make expenditure in accordance with the budget provisions. It is the budget that establishes and communicates the objectives and priories of governing units. It is asserted[8] that budgeting promotes planning, coordination, enhances performance measurement and introduces corrective actions. Management uses budget a base to initiate expenditure actions. Previous budgets help governments to tract the level of success or failure achieved over the years. In order to keep track of activities that need to be included in the Budget document, many Government organizations prepare their budgets based on incremental rather than other types of budgeting. It is observed by[9] that the use of the revised current year estimates of income and expenditure as a starting point for determining the budget for next year is frequently claimed to be one of the most fundamental weakness of the budgetary process. It is urged that such an approach fails to consider whether a particular item is still required or whether the amount currently incurred is reasonable. Once an item appears in the budget at inception, its inclusion in future budgets is taken for granted and only incremental changes in the item are considered. In this type of situation, attention is therefore focused on the marginal or incremental difference between this year's budget and last year's budget rather than on the whole of the budget, and it is this that gives rise to the term incremental budgeting.

In Nigeria to overcome the lapses of incremental budgeting, what is in vogue and encouraged by current administration is clean slate type of budgeting which is otherwise known as zero based budgeting. At the end of the year all unspent money will be returned to treasurer. Some ministries often find it difficult to return such money so they resort to looking for activities that will allow spending of more money in order to spend their budget. This act has prompted a new terminology called 'Budget Engineering'. A balanced scorecard budget obviates budget engineering found in both incremental and zero based budgeting process and budgets.

It is the opinion of [10] that for budget to be translated into concrete development and growth there must be a real forecast of goals or targets at all the tiers of governments. The essence of Governments relying on budget is because it serves as a map of activities at all tiers of government. Reliable, accurate and timely presentation of budget will facilitate early government goals attainment. In order to draw Governmental map of activities, budget may be formed from a 'Balanced' or 'Unbalanced' locus. According to the author of[11] a balanced budget is a situation in which estimated revenue of the Government during the year is equal to its anticipated expenditure while that of unbalanced budget is a situation whereby Income and Expenditure are not equal to each other. The unbalance may turn to be a surplus or deficit budget. A budget is termed 'Surplus' where revenues are estimated to be greater than projected expenditures, while 'Deficit' budget represents a situation where estimated revenues are less than projected expenditures.

Budget may also be classified based on time frame. In the words of [8] Capital budget is a long-term plan regarding investments in facilities, equipment or other lines of governmental ventures. According to the author in[12] Operating budget captures the routine revenue and expenses of 
different levels of government for a short time frame. In Nigeria, Operating budget is called Recurrent Expenditure Budget. Recurrent Expenditure Budget covers a time frame of one year, starting from January to December each year.

Balanced Scorecard perspective of Budget is what [13] had in mind while stating that for budget to achieve its functions of compelling planning, provide performance, promote communication and coordination, it had to be administered 'intelligently'. One of the founders of Balanced Scorecard Budget perspective is[14] who asserted that the Balanced Scorecard is a communications tool to make strategy clear to everyone and it is a system for increasing accountability. In the Governance parlance, balanced scorecard pertains to serving Country by helping improve the lives of the people and community. It is about increasing value by providing more cost-effective services within the ambits of the Budget. To the Business sector, it deals with increasing business opportunities and raising quality of goods and services provision.[15], citing Rohm, 2005 agreed that Balanced Scorecard is a tool that measures performance based on strategy and objectives. On definition and explanation of balanced scorecard,[15] quoting Procurement Executives' Association, 2005 defined the Balanced Scorecard as a conceptual frame work for translating an organization's strategic objectives into a set of performance indicators distributed among four perspectives of; Financial, Customer, Internal Business processes and Growth. We know that Customer in government terminology is the populace/community and Internal business processes represents the Government employees. However,[15] described the areas of emphasis of these four perspectives as follows; Emphasis on financial perspective is on cost and the ability to provide the best value to Government stakeholders. Customer perspective focuses on the agency's overall responsibility to meet the customers/populace needs in the most efficient and effective manner. The focus of Internal Business processes is on performance expectations and ensuring the proper processes and resources are available and implemented to maximize performance. Continuing [15] asserted that Growth perspective emphasis is on the employee ability and the organizational structure needed to achieve the agency's goals'

Balanced scorecard perspective of budget is not same as balanced budget. The author of[11] summarized balanced budget by asserting that it is a situation in which estimated revenue of the Government during the year is equal to its anticipated expenditure.

Budget from which perspective, it is prepared and implemented; there exist various forms of threats and weaknesses that may stand on the way. Such weakness or threats centers around: Overestimation of the revenue budget, Inability to harness several of revenues, Lack of adequate manpower to man various revenues collection points properly, Lack of qualified personnel who can introduce new innovations, lack of motivation by work force, difficulty of tracing tax payers, poor communication links. Asserted by[16] is that the validity of budget to a large extent is de- termined by the accuracy with which the estimates are made. The operating effectiveness of a governmental unit is clearly dependent upon how well Political officer holders are able to motivate the employees to operate within the budgeted allowance. In addition,[17] propounded that budgeting is not only costly and time consuming both in preparation, securing approval and forecloses but also are generally backward-looking and inward-oriented instead of being market-oriented thus it inevitably provide irrelevant and unreliable data to users. Many a time Government budgets in developing countries like Nigeria is nothing but addition of figures only to be read to the ears of the public.

The budget document which is a plan of activities is expected to be followed item after item in its implementation and execution. It appears that some departments, establishments, ministries in local, state or federal government levels do not follow the budgets closely. Thus leads to unaccomplished items of the budget of that unit. Departure from budget items amount to disastrous development, conflicts, scandals and corruption of administration. The aim of this paper is to evaluate budget in the public sector from balanced scorecard perspectives.[18] reporting on the announcement of George Osborne (2010) states that the deepest cuts ever seen in the British public sector by ordering nearly all government departments to slash an average of $25 \%$ from their annual budgets before the next general election and announcing a two-year pay freeze for all public sector employees tells you how political priorities many a time overrides economic considerations in Government budgets.

Government budgets sets limits of expenditure for the good of the state but many a time these limits are draconian cuts from the People's welfare as inferred from[19].

Public servants many a time are cornered to bear an unfair share of the burden of previous mismanagements of resources by Political Office holders as expressed by[10].

In addition to the aforementioned budget after effects, the laws of State always require procedures and phases of budget preparations, processing and use. After the budget discussion, preparations, approval, signing by the chief executive, is not only time wasting procedure but exerts negative pressures on budget performance.

These negative aspects of budget notwithstanding, there are a consensus for the need to plan. Budget is a plan of future actions expressed in financial terms. Nigeria had put forward her vision for 2020 and one of the strategies for achieving this vision is implementations of Balanced Scorecard Budget perspective. Advocating reasons for implementation of a balanced scorecard budget,[15] citing Niven, 2003 advanced the following;

- It improves performance,

- Demonstrate accountability,

- Meet Constituents needs,

- Align Departmental and Workers goals with Governmental goals and

- Improve Communication with the Ministries and Government. 
Vision 2020 is not the first strategic vision set out by Nigeria. Preceding Vision 2020 was 2010. How well was Vision 2010 achieved? Stakeholders in Nigeria are yet to be properly informed. Performance measures need to be set along with these visions for performance measures are indicators of success, communicated to all the stakeholders at the time of setting out strategic visions or objectives. Performance measures revolve around results, accomplishments and impacts of Budget to the different stakeholders.

\section{Research Methods}

The study covers Borno, Bauchi, Yobe, Taraba and Adamawa states. These states were selected because they are within same geographical, cultural and developmental location. In these states, structured questionnaire was administered on target participants namely Administrators, Accountants, Financial Sector employees, Government Workers and Business representatives. The mean Reponses of the participants were obtained and tested at 5\% level of significance.

A total of six hundred questionnaires were administered in each state to willing participants from each of the four selected performance indices. The question was simply, designed to address the research objectives and hypothesis. The research objectives are; to investigate how budget perform- ance differs from state to state in Nigeria and to carry out a correlation appraisal of surveyed States and responses obtained on budget performances of the selected states in $\mathrm{Ni}$ geria from years 2000 to 2010, thus invoking the following research hypotheses:

H01: Budget performance among the selected States over a ten year period is not significantly different.

H02: The correlation of responses obtained among the surveyed States is not significantly different.

Four budget performances perceptive of Financial Sectors, Workers' Welfare Needs, Business Evolutions \& Sustenance and General Economic Growth \& Development of the States were chosen as indices. Categorical assertions on each of these indices were collected using questionnaire but analyzed with SPSS version 16 based ANOVA (Analysis of Variance) statistical tool for null hypothesis one and T-test Pair Wise Correlation for null hypothesis two. The tests were conducted $95 \%$ confidence level

\section{Results and Discussions}

The responses captured from the question (From your experience, your state significantly planned, processed and implemented her budgets between years 2000 to 2010? Tick Yes or No) are as seen in table 1.

Table 1. Public Sector Budget performances between 2000 to 2010 fiscal years, opinions obtained from survey

\begin{tabular}{|c|c|c|c|c|c|}
\hline Perspectives & Borno & Bauchi & Yobe & Taraba & Adamawa \\
\hline Financial & $72(57)$ & $29(142)$ & $66(102)$ & $29(122)$ & $64(79)$ \\
\hline Workers & $57(72)$ & $57(72)$ & $72(60)$ & $23(100)$ & $70(86)$ \\
\hline Business & $142(29)$ & $29(142)$ & $29(142)$ & $72(134)$ & $72(67)$ \\
\hline Growth & $29(142)$ & $72(57)$ & $57(72)$ & $50(70)$ & $20(142)$ \\
\hline
\end{tabular}

Source: Field work, 2011

Numbers in brackets represent 'No' (Negative) responses to balanced scorecard perspectives of their state budget performances

Table 2. ANOVA (Analysis of Variance) of the budget performances of the selected States

\begin{tabular}{|c|c|c|c|c|c|c|}
\hline & & Sum of Squares & df & Mean Square & $\mathrm{F}$ & Sig. \\
\hline \multirow{3}{*}{ Perspectives } & Between Groups & .000 & 1 & \multirow{3}{*}{$\begin{array}{c}.000 \\
1.316\end{array}$} & \multirow[t]{3}{*}{.000} & \multirow[t]{3}{*}{1.000} \\
\hline & Within Groups & 50.000 & 38 & & & \\
\hline & Total & 50.000 & 39 & & & \\
\hline \multirow{3}{*}{ States Surveyed } & Between Groups & .000 & 1 & \multirow{3}{*}{$\begin{array}{c}.000 \\
2.105\end{array}$} & \multirow[t]{3}{*}{.000} & \multirow[t]{3}{*}{1.000} \\
\hline & Within Groups & 80.000 & 38 & & & \\
\hline & Total & 80.000 & 39 & & & \\
\hline \multirow{3}{*}{ Frequency of Responses } & Between Groups & 78.400 & 1 & \multirow{3}{*}{$\begin{array}{c}78.400 \\
5.976\end{array}$} & \multirow[t]{3}{*}{13.118} & \multirow[t]{3}{*}{.001} \\
\hline & Within Groups & 227.100 & 38 & & & \\
\hline & Total & 305.500 & 39 & & & \\
\hline
\end{tabular}




\subsection{Discussion of Results and Outcome of Test of Hypothesis}

The data captured by table 1 were codified for execution on SPSS based Analysis of Variance, producing result as shown in table 2 . The outcome of table 2 shows that null hypothesis one which states Budget performance among the selected States over a ten year period is not significantly different should be rejected. The result shows that budget performance among the selected states are significantly different as $\mathrm{p}=.001$ which less than $5 \%$. This implies that budget performances differ from State to State as well as from Ministry to Ministry.

Table 3. Paired Samples Correlations of the sampled States

\begin{tabular}{|l|c|c|c|c|}
\hline & & $\mathrm{N}$ & Correlation & Sig. \\
\hline Pair 1 & $\begin{array}{c}\text { Perspectives \& Frequency } \\
\text { of Responses }\end{array}$ & 40 & .049 & .766 \\
\hline Pair 2 & $\begin{array}{c}\text { States Surveyed \& Fre- } \\
\text { quency of Responses }\end{array}$ & 40 & .000 & 1.000 \\
\hline Pair 3 & $\begin{array}{c}\text { Responses \& Frequency } \\
\text { of Responses }\end{array}$ & 40 & .507 & .001 \\
\hline
\end{tabular}

To validated the decision on null hypothesis one, we propounded hypothesis two which stipulates that the correlation of responses obtained among the surveyed States is not significantly different. This is deemed necessary to eliminating skewed or very overbearing responses from one state that influenced generalization to all the sampled states. To test hypothesis two of this research, we used results shown in both tables 3. From table 3, States surveyed and Frequencies of Responses is insignificant, thus we accept the assertion of the null hypothesis two. Like the results shown by table 1, the Paired Samples Correlations of the sampled States indicates that what is significantly different is the frequency of responses on budget performances among the selected states, again giving credibility to our rejection of null hypothesis one.

\section{Conclusions and Recommendations}

Budget is a document that aids management in planning, sourcing of funds and the execution of activities or projects. It facilitates service delivery to the people at the various levels of governance. It tries to compare budgeted plans with actual plans. It serves as a mirror as well as monitoring instrument of control. The paper traces the origin of budget from a French word called bougette, meaning little bag. This little bag contains what people need. The results showed that budget performance differs from state to state but this difference notwithstanding we recommend that Nigeria adopt Balanced Scorecard Budget perspectives and close monitoring of budget execution should be enshrined in work ethics of our country so as to strengthen other measures in mitigating public corruption in Nigeria. Controls of the budget should be made ethically paramount. Any spending outside the budget must obtain the consent of the executive.
Independent body is expected to check, monitor, and investigate the execution of budget of every tiers of government as it is done elsewhere like USA, UK and developed nations of the world. Fiscal Responsibility Commission should be given high degree of independence to oversee the implementation and execution of the budgets of government at all the three tiers of government. This can be done by enforcing rule of law of budget implementation any unauthorized spending should be report to the appropriate authority for disciplinary action. Nigeria needs to adopt Balanced Scored Budget perspectives to ease achieve her aspiration to be among the top 20th economies of the world by the year 2020 . Key indicator of performance and growth is the embedment of budget discipline at all the tiers of government, thus money spent must be justified and satisfied by all the established budgetary and budget monitoring organs. Balanced Scorecard of Budget preposition not only aligns strategy and objectives but also stipulates performance measures necessary to evaluate strategic visions or mission statements.

\section{REFERENCES}

[1] Omolehinwa, Ade (2005): Work Out Management Accounting, CIO International, Lagos Nigeria P538

[2] Lane H. W \& DiStefano (1988): International Management Behavior - From Policy To Practice Nelson Canada, Ontario, p92

[3] Noreen E.W., Garrison R.H and Folk J.M (2002): Introduction to Managerial Accounting McGraw-Hill Higher Education New York, USA Pp 276-280

[4] Reeve J.M \& Warren C.S (2008): Principles of Financial and Managerial Accounting Thomson Higher Education New York, USA Pp932- 938

[5] Mbieli Patrick (2006): Public Policy Ometek Publishers Ltd Onitsha, Nigeria P 110

[6] Edwards J.R (1994): Accountancy for Banking Students, The Chartered Institute of Bankers P453

[7] Baker Richards (2005): Advanced Financial Accounting, McGraw-Hill Higher Education, New York, USA P 869

[8] Edmonds T.P, Edmonds C.D, Olds P.R, McNair F.M, Tsay B, Schneider N.W and Milam E.E (2007): Fundamental Financial and Managerial Accounting Concepts, McGraw-Hill Higher Education, New York, USA Pp 1021- 1034

[9] Langfield S.K, Thorne H and Hilton T.W( 2006): Management Accounting 4th edition, McGraw-Hill, Australia Pty Limited, Pp400 -440

[10] Secett, M. (1993): Mastering spreadsheet Budgets and forecasts, A practical guide. www.guardian.co.uk, Assessed on 04/06, 2010

[11] SAP.com (2010): Public Sector Budgets, www.SAP.com/ind ustries/public sector/pdf 2010, Retrieved on 3/12/2011

[12] ehow.com (2011): Types of Government Budgets, 
http://www.ehow.com/list_6883310_types-govenment-budg ets.html, Retrieved on 29/11/2011

[13] Horngren T.C (1982): Cost Accounting; A Managerial Emphasis 5ed, Prentice-Hall, Englewood Cliffs, New Jersey, P131

[14] Rohm Howard (2002): Improve Public Sector Results with a Balance Scorecard: Nine Steps to Success, www. balancescorecard.org, Assessed on 23/11/2011

[15] Smith Jean M (2006): Using a Balanced Scorecard as a strategic tool in public purchasing, A paper presented at International Public Procurement Conference, September 2006,
Conference Proceedings Pp 901 -906

[16] Osuala E.C (1990): Teach yourself Business Management, Africana First Publishers Ltd, Onitsha Nigeria Pp254- 257

[17] Abrams J.H (1982): The Limitations of Budgets, Analysis, The Government Accountant Journal (e-vision), Arlington Spring USA, P353

[18] Rosa, P (2010): Budget 2010: Two year pay freeze for public sector, www.guardian.co.uk/jun, 2010, Assessed on $6 / 12 / 2011$

[19] Polly, C. (2010): UK News budget 2010. www.SAP.com/ind ustries/pdf.2010, Retrieved on 2/12/2011 